\title{
Effect of mesenchymal stem cell in liver regeneration and clinical applications
}

\author{
Seong Min Lee ${ }^{1, \#}$, Seung Duk Lee ${ }^{2, \#}$, Sarah Ziqi Wang ${ }^{1}$, Devanand Sarkar ${ }^{3}$, Hannah M. Lee ${ }^{4}$, Aamir Khan $^{2}$, \\ Chandra Bhati ${ }^{2}$, Amit Sharma ${ }^{2}$, Vinay Kumaran ${ }^{2}$, David Bruno ${ }^{2}$, Adrian Cotterell ${ }^{2}$, Marlon F. Levy ${ }^{2}$ \\ 1School of Medicine, Virginia Commonwealth University, Richmond, VA 23298, USA. \\ ${ }^{2}$ Division of Transplant Surgery, Department of Surgery, Virginia Commonwealth University, Richmond, VA 23298, USA. \\ ${ }^{3}$ Department of Human and Molecular Genetics, Virginia commonwealth University, School of Medicine, Richmond, VA 23298, \\ USA. \\ ${ }^{4}$ Division of Gastroenterology, Hepatology, and Nutrition, Virginia Commonwealth University, Richmond, VA 23298, USA. \\ \#Authors contributed equally.
}

Correspondence to: Dr. Marlon F. Levy, Department of Surgery, Virginia Commonwealth University, 1200 E Broad St PO Box 980645, Richmond, VA 23298, USA. E-mail: marlon.levy@vcuhealth.org

How to cite this article: Lee SM, Lee SD, Wang SZ, Sarkar D, Lee HM, Khan A, Bhati C, Sharma A, Kumaran V, Bruno D, Cotterell A, Levy MF. Effect of mesenchymal stem cell in liver regeneration and clinical applications. Hepatoma Res 2021;7:53.

https://dx.doi.org/10.20517/2394-5079.2021.07

Received: 25 Jan 2021 First Decision: 6 Apr 2021 Revised: 7 Apr 2021 Accepted: 12 Apr 2021 First online: 1 Jul 2021

Academic Editors: Giuliano Ramadori, Isabel Fabregat Copy Editor: Xi-Jun Chen Production Editor: Xi-Jun Chen

\begin{abstract}
Liver disease accounts for approximately 2 million deaths per year worldwide with cirrhosis, viral hepatitis, and malignancy being the most common causes. Consequently, the regenerative capacity of the liver is a topic of extreme interest in the search for curative therapies to end-stage liver disease. Mesenchymal stem cells (MSCs) have emerged as a promising new therapy for hepatic regeneration. MSCs have multiple properties that make them an appropriate treatment option for liver disease including easy accessibility, targeted migration, immunomodulatory potential and antifibrotic/antioxidant effects. Additionally, MSCs have potential clinical applications in acellular therapy and tissue engineering. Liver regeneration with concurrent attenuation of liver injury makes MSCs a compelling therapeutic target in the setting of severe liver disease. This review outlines the mechanisms of MSC-driven liver regeneration and suggests potential clinical applications.
\end{abstract}

Keywords: Mesenchymal stem cell, liver regeneration, end-stage liver disease 


\section{INTRODUCTION}

The liver is constantly subjected to noxious damage from both exogenous and endogenous toxins, thus requires a method to recover from injury. Normal liver regeneration is achieved primarily through proliferation of existing mature hepatocytes and biliary epithelial cells (BECs) ${ }^{[1]}$. Studies have demonstrated that regeneration of the liver following hepatectomies are characterized by phenotypic fidelity, meaning each cell is responsible for propagating its own cell type ${ }^{[2]}$. That is, hepatocytes make other hepatocytes, and the same applies to most other liver cell types including BECs and hepatic stellate cells (HSCs). Stem cells are not typically associated with physiologic liver proliferation, with the exception of Kupffer cells and liver sinusoidal endothelial cells (LSECs), both of which can be derived from bone marrow stem cells ${ }^{[3]}$. Of note, in the setting of impaired hepatocyte or BECs proliferation, the unaffected cell type can transdifferentiate into the impaired cell type and effectively function as facultative stem cells ${ }^{[4]}$.

Despite the exceptional regenerative capacity of the liver, chronic injury can overwhelm the liver's ability to regenerate and this leads to fibrosis. Liver fibrosis is a secondary wound healing process driven by myofibroblasts to degrade normal extracellular matrix (ECM) and accumulate excess connective tissue $e^{[5]}$. The majority of myofibroblasts in liver fibrosis is derived from trans-differentiation of quiescent HSCs, which lead to activation of matrix metalloproteinases (MMPs) and tissue inhibitors of MMPs (TIMPs) ${ }^{[6]}$. A subset of myofibroblasts are derived from portal myofibroblasts and bone marrow (BM)-derived fibrocytes $^{[7]}$. Portal myofibroblasts drive fibrogenesis exclusively in the biliary system, while the BM-derived fibrocytes minimally contribute to hepatic fibrosis ${ }^{[7]}$. Interestingly, fibrocytes share many phenotypic features with MSCs. Fibrocytes are BM-derived, collagen type 1 producing cells that produce ECM components and contribute to liver fibrosis. Fibrocytes appear to have regenerative properties and express surface markers like CD11b, CD14, CD 34, CD45 and $\alpha$-smooth muscle antibody (SMA) that are seen in cells of hematopoietic lineage ${ }^{[8]}$. However, fibrocytes lack the heterogeneity of MSCs and have unique proteomes that suggest BM-derived fibrocytes are distinct from $\mathrm{MSCs}^{[0]}$. Regardless of the source of myofibroblasts, they all express high levels of fibrillar collagen, TIMPs, and they are dominant contributors to liver fibrosis ${ }^{[5]}$.

Currently, liver transplantation is the only definitive treatment for end-stage liver disease (ESLD). Fortunately, improvements in immunosuppressive drugs and surgical methods have improved transplantation outcomes and the global organ transplantation market is projected to grow significantly through the next few years ${ }^{[10]}$. The wide range of therapeutic potential of MSCs can further improve outcomes in ESLD as adjuvant or alternative therapy to liver transplantation. First, MSCs are pluripotent stem cells capable of differentiating into hepatocyte-like cells both in vivo and in vitro ${ }^{[1,12]}$. Second, MSCs are readily accessible from multiple potential sources including adipose tissue, umbilical cord (UC), umbilical cord blood, peripheral blood, synovial membranes, muscle, dermis, and liver ${ }^{[13-17]}$. Importantly, the harvested MSCs maintain their pluripotent potential, robust proliferative ability, and capacity for ex vivo expansion ${ }^{[18]}$. Third, MSCs have the ability to migrate and engraft at sites of injured tissue ${ }^{[19]}$. Fourth, MSCs have immunosuppressive properties that allow for allogeneic transplantation. The immunosuppressive ability of MSCs also includes anti-fibrotic and antioxidant effects which can protect the liver from fibrosis and oxidative damage ${ }^{[20]}$. Lastly, MSCs produce extracellular vesicles (EV) that contain growth factors and cytokines that promote regeneration of impaired tissue such as liver parenchyma ${ }^{[20]}$. In this review, we will focus on the potential therapeutic mechanisms of MSCs and future studies that can help develop more effective treatments for ESLD [Table 1].

\section{HOMING AND MIGRATION OF MSCS IN LIVER REGENERATION}

A major criterion for effective stem cell therapy is the induction and engraftment of cells into the region of 
Table 1. Advantages and disadvantages among different cell types for treatment of liver disease

\begin{tabular}{lll}
\hline Cell type & Advantages & Disadvantages \\
\hline Hepatocytes $^{[21]}$ & $\begin{array}{l}\text { Key metabolic and synthetic cell of liver, suitable for replacing enzyme deficiency } \\
\text { and in metabolic disorders }\end{array}$ & $\begin{array}{l}\text { Donor shortages, limited engraftment and } \\
\text { proliferation, infection risk }\end{array}$ \\
$\begin{array}{l}\text { Hemopoietic } \\
\text { cells }^{[22,23]}\end{array}$ & $\begin{array}{l}\text { Pluripotency } \\
\text { Requires bone marrow aspiration }\end{array}$ \\
Immune cells $^{[24]}$ & Relatively easy to isolate and culture & Can lead to inflammatory storms \\
EPCs $^{[25,26]}$ & Antifibrotic and pro-regenerative & $\begin{array}{l}\text { Complicated isolation process, unclear } \\
\text { clinical efficacy }\end{array}$ \\
MSCS $^{[27-30]}$ & $\begin{array}{l}\text { Relatively easy to isolate and culture, pluripotent, immunomodulatory, anti- } \\
\text { inflammatory, anti-fibrotic, extracellular signaling, allograft potential }\end{array}$ & $\begin{array}{l}\text { Pro-tumor potential } \\
\text { Risks of isolation procedures }\end{array}$ \\
\hline
\end{tabular}

EPCs: Endothelial progenitor cells; MSCs: mesenchymal stem cells.

damage. The regenerative potential of MSCs in ESLD is largely reliant on the MSCs' ability to migrate to the liver following administration. MSCs homing involves initial tethering by selectins, activation by cytokines, arrest by integrins, and extravascular migration towards chemokine gradients ${ }^{[31]}$. Tissue injury releases stress signals that attract MSCs to the site of damage ${ }^{[32]}$. Molecules expressed on MSC surfaces such as CXCR4, Eselectin, CD44, VLA-4, VCAM-1, and TIMP3 facilitate the subsequent adhesion, activation, and migration into damage tissue ${ }^{[33]}$. Unfortunately, MSC homing is inefficient and only a small percentage of cells reach the target tissue following systemic administration. In rat models of carbon tetrachloride (CCl4)-induced liver necrosis treated with green fluorescent protein (GFP)-labeled MSCs, the quantity of GFP-labeled MSCs detected in the liver was significantly less than what would be expected compared to the injected quantity ${ }^{[34]}$. In vivo studies have shown that a large fraction of MSCs become trapped in the lung after intravenous injection ${ }^{[35]}$. However, there is evidence that pretreatment with vasodilators significantly increases MSC homing to the site of injury ${ }^{[35]}$.

Multiple studies have demonstrated that the stromal cell-derived factor (SDF)-1a plays an important role in stem cell homing, chemotaxis, engraftment, proliferation, and survival ${ }^{[36-42]}$. SDF-1a is a chemotactic protein of the CXC family of proteins produced by bone marrow stromal cells. SDF-1a and its receptor chemokine CXC receptor 4 (CXCR4) are expressed in a variety of cells and tissues including immune cells, brain, heart, liver, kidney, lung, and spleen ${ }^{[43]}$. SDF-1a promotes the migration of stem cells to damaged tissue by binding to CXCR4 on stem cell membranes ${ }^{[40-42]}$. CXCR4 expression is endogenously regulated by tissue environmental factors such as cytokines, chemokines, stromal cells, adhesion molecules, tissue damage, and hypoxia $^{[44]}$. For example, hypoxic conditions in the kidney appeared to increase CXCR4 expression of MSCs which enhanced functional recovery, accelerated mitogenic response, and reduced cell death ${ }^{[45]}$. This finding is further supported by rat models of myocardial infarction where increased expression of CXCR4 maximized the effect of SDF-1a to increase MSC migration and cardiac tissue regeneration ${ }^{[46]}$.

SDF-1a is a potent chemoattractant for cells expressing CXCR4, and studies have demonstrated increased concentrations of SDF-1a in the liver following acute liver injury ${ }^{[47]}$. However, MSCs have low native levels of CXCR4 which could explain the poor mobilization of MSCs in the setting of liver disease ${ }^{[48]}$. Furthermore, MSCs gradually downregulate the expression of CXCR4 after culturing and these cells lose the ability to migrate towards SDF-1 $\mathrm{a}^{[49]}$. In a study of MSC stimulated regeneration of reduced size liver transplants, CXCR4 overexpressed rats exhibited enhanced MSC engraftment following MSC therapy with improved hepatocyte proliferation and increased survival compared to control ${ }^{[50]}$. Interestingly, the engrafted MSCs did not express markers of hepatocytes suggesting that these cells promoted regeneration of the remnant liver by a paracrine (relating to, promoted by, or being a substance secreted by a cell and acting on adjacent cells) mechanism. A subsequent study of genetically modified MSC with CXCR4 
overexpression demonstrated similar results with increased migration and engrafted of MSC at the liver following acute liver failure ${ }^{[48]}$. This study also demonstrated significantly increased levels of hepatocyte growth factor (HGF) and vascular endothelial growth factor (VEGF), again indicative of the presence of additional paracrine signaling that stimulates endogenous liver regeneration.

\section{MSC DIFFERENTIATION INTO HEPATOCYTE-LIKE CELLS}

MSCs are pluripotent stem cells with the potential to differentiate into cells of all three germ layers, including the endoderm, mesoderm, and ectoderm. In both in vivo and in vitro experiments, MSCs have demonstrated the ability to differentiate into hepatocyte-like cells with liver-specific morphology and function in the presence of cytokines and growth factors including HGF, fibroblast growth factor (FGF), oncostatin M (OsM), epidermal growth factor (EGF), leukemia inhibitory factor, and insulin-like growth factor (IGF) ${ }^{[51]}$. This pluripotent capacity is demonstrated by the presence of human hepatocyte markers such as albumin, $\alpha$-fetoprotein (AFP), CK18, and CK19 in liver tissue of cirrhotic rats after human UCderived MSC administration ${ }^{[52]}$. These hepatocyte markers were not detected prior to MSC injection and there was no detection of rat-lineage hepatocyte albumin, AFP, CK18, or CK19, suggesting the transplanted human UC-derived MSCs were entirely responsible for differentiating into hepatocyte-like cells.

Although MSCs can be induced to differentiate in culture, an organ-specific microenvironment is the most suitable method for differentiation into a specific cell type ${ }^{[53]}$. Hepatic-differentiated cells are characterized by the expression of hepatocyte-specific genes and these genes are influenced by the microenvironmental conditions ${ }^{[54]}$. Studies have demonstrated that human UC-derived MSCs differentiated into hepatocyte-like cells more rapidly when in a fibrotic liver microenvironment, mimicked by rat fibrotic liver tissue extract ${ }^{[55]}$. Allyl alcohol-treated rat liver models have demonstrated human MSCs ability to convert into functional hepatocyte-like cells when directly administered intra-hepatically to damaged rat liver ${ }^{[56]}$. Notably, liver function was restored within a week of transplantation through mechanisms suggestive of microenvironmental cues rather than cell fusion ${ }^{[56]}$.

Zhang et al. ${ }^{[52]}$ have demonstrated that MSCs do not directly differentiate into functional hepatocytes; instead, they first differentiate into BEC-like cells and subsequently differentiate to hepatocyte-like cells. In contrast, other studies indicate that trans-differentiation of MSCs is rare following MSC infusion in animal models ${ }^{[54]}$. For example, menstrual blood-derived MSCs were shown to inhibit HSC and liver fibrosis, thus improving liver function ${ }^{[54]}$, but only a small fraction of the transplanted MSCs differentiated into functional hepatocyte-like cells ${ }^{[57]}$. Based on these findings, the current understanding is that MSCs exert their therapeutic effects through both direct cell differentiation and indirect paracrine signaling [Table 2].

\section{SECRETION OF TROPHIC FACTORS FOR LOCAL AND SYSTEMIC SIGNALING}

The therapeutic effects of transplanted MSCs were initially thought to be solely mediated by their migration to the site of injury, where integration and differentiation would take place. However, studies have shown that only a small proportion of MSCs have been observed to actually engraft and proliferate in the damaged tissue $^{[58]}$. One proposed explanation is that MSCs elicit their therapeutic effects through the secretion of trophic factors. MSCs release a collection of trophic factors that signal for the regeneration of damaged tissues. These factors include growth factors, cytokines, and chemokines, which not only reduce the inflammation, apoptosis, and fibrosis of damaged tissues but also stimulate angiogenesis and tissue cell regeneration ${ }^{[58]}$. Local inflammatory cytokines, ligands of Toll-like receptors (TLRs), and hypoxic conditions all stimulate MSC migration to sites of cell damage. These conditions increase the production of MSCreleased growth factors and enhance the regenerative processes ${ }^{[59,60]}$. 
Table 2. Sources for MSC harvest, growth factors for differentiation, and markers of differentiation into hepatocyte-like cells

\begin{tabular}{lll}
\hline Source of MSC $^{[13-17]}$ & Growth factors $^{[51]}$ & $\begin{array}{l}\text { Markers of hepatocyte-like } \\
\text { differentiation }^{[52]}\end{array}$ \\
\hline $\begin{array}{l}\text { Adipose, UC, UC-blood, peripheral blood, synovial } \\
\text { membranes, muscle, dermis, liver }\end{array}$ & $\begin{array}{l}\text { HGF, FGF, OsM, EGF, leukemia } \\
\text { inhibitory factor, IGF }\end{array}$ & Albumin, AFP, CK18, CK19 \\
\hline
\end{tabular}

MSC: Mesenchymal stem cell; UC: umbilical cord; HGF: hepatocyte growth factor; FGF: fibroblast growth factor; OsM: oncostatin M; EGF: epidermal growth factor; IGF: insulin-like growth factor; AFP: $\alpha$-fetoprotein.

In the setting of liver fibrosis, MSC-secreted trophic factors can increase hepatocyte survival via antiapoptotic (stromal cell-derived factor 1, HGF, IGF-1, and VEGF), mitogenic [EGF, HGF, nerve growth factor (NGF), and transforming growth factor alpha (TGF- $\alpha$ )], and angiogenic effects (VEGF) ${ }^{[61-63]}$. Trophic factors lengthen the replicative cycle of injury and repair of both living and dying hepatocytes ${ }^{[63]}$. MSC transplantation was also associated with alterations in HGF and IGF-1 expression that correlated with reduced inflammation of fibrotic tissue during anti-apoptotic events ${ }^{[6,65]}$. HGF, EGF, and TGF- $\alpha$ are potent mitogens primarily associated with hepatocyte proliferation and VEGF enhances angiogenesis which is crucial for liver regeneration ${ }^{[6-69]}$. In addition to hepatocytes, hepatic progenitor cells, which are located in the Canals of Herring, can be differentiated into hepatocyte-like cells or biliary lineage cells following treatment with EGF or HGF, respectively ${ }^{[70]}$. Trophic factors, such as IL-10, HGF, NGF, TGF- $\beta$ and tumor necrosis factor (TNF)- $\alpha$ regulate the proliferation of activated HSCs and decrease collagen synthesis in liver fibrosis $^{[7]}$.

Several studies on MSC-derived extracellular vesicles support the theory of paracrine signaling in MSCbased liver therapy. MSC-derived EVs contain MSC trophic factors that protected mouse liver against $\mathrm{CCl} 4$-induced injury by activating proliferative and regenerative responses ${ }^{[72]}$. A study demonstrated that EVs suppressed toxin-induced hepatocyte apoptosis by promoting the expression of anti-apoptotic protein B-cell lymphoma-extra large (Bcl-xL). EVs isolated from human UC-derived MSCs showed reduction in hepatic inflammation and collagen deposition of CCL4-induced fibrotic liver ${ }^{[73]}$. Additionally, there was an increase in liver aspartate transaminase (AST) activity, suggestive of functional liver recovery. MSC-derived EVs also demonstrated immunosuppressive properties associated with MSCs such as upregulation of T regulatory (Treg) cells and anti-inflammatory cytokines ${ }^{[74,75]}$. Further research on the exact mechanism of MSC-derived trophic factors is important for determining how MSCs exert their effects of liver regeneration and can subsequently lead to more targeted therapy for severe liver disease [Table 3].

\section{MSC AND REGULATION OF IMMUNOLOGIC RESPONSE}

MSCs exert an immunosuppressive effect through a multifaceted approach. MSCs have low expression of major histocompatibility complex (MHC)-II and costimulatory cell surface markers which is a major reason behind its allograft potential ${ }^{[76]}$. MSCs also directly interfere with immune response through direct cell-tocell interactions and secretion of soluble factors. For instance, MSCs can inhibit cell proliferation of T-, B-, natural killer (NK)-, and dendritic cells (DC) to induce cell division arrest anergy ${ }^{[77]}$. MSCs stop a wide range of innate and adaptive immune cell functions through the cytotoxicity of T and NK cells, B cell antibody secretion, inhibition of monocytes, DC antigen presentation, induction of apoptosis via programmed death (PD)-1, and upregulation of Tregs, especially in the setting of inflammation which activates $\mathrm{MSCs}^{[77]}$.

MSCs secrete immunomodulatory factors, including nitric oxide (NO), prostaglandin E2 (PGE2), indoleamine 2,3-dioxygenase (IDO), human leukocyte antigen (HLA)-G, IL-6 and -10 $0^{[77]}$. MSC induction of NO synthase (NOS) is a major mechanism for T cell suppression by MSCs, while IDO and TGF- $\beta$ had more 
Table 3. Clinical application of MSCs in treatment of ESLD

\begin{tabular}{lll}
\hline Clinical applications & MSC properties & Ref. \\
\hline Priming & SDF-1a, CXCR4 upregulation improves targeting of MSC & {$[38-44,140-142]$} \\
& Enhanced survival with ZD & {$[60-65]$} \\
Cell-free therapy & Anti-apoptotic, mitogenic, angiogenic effects through trophic factors & {$[151-155]$} \\
Genetic modifications & HSP-20, Akt, SDF-1b, HIF-1a, FGF-2 overexpression lead to increased cell survival & {$[170-172]$} \\
Tissue engineering & EX-vivo culture can be implemented in 3D liver scaffolds to print transplantable organ & \\
\hline
\end{tabular}

MSCs: Mesenchymal stem cells; ESLD: end-stage liver disease; SDF-1a: stromal cell-derived factor-1a; CXCR4: CXC receptor 4; ZD: zeaxanthin dipalmitate; HSP-20: heat shock protein-20; SDF-1b: stromal cell-derived factor-1b; HIF-1a: hypoxia-inducible factor-1a; FGF-2: fibroblast growth factor-2.

questionable effects ${ }^{[78]}$. PGE2 exhibits multiple immunomodulatory effects, such as cell proliferation, apoptosis, tissue repair, angiogenesis, anti-inflammation, immune surveillance, and anti-cancer ${ }^{[79-81]}$. PGE2 release has significant anti-inflammatory properties, specifically by stimulating the synthesis of antiinflammatory cytokine IL-10 and by decreasing the synthesis of pro-inflammatory cytokines such as tumor necrosis factor (TNF)- $\alpha$, interferon (IFN)- $\gamma$, and IL-12 from DCs. MSC-secreted PGE2 has additional antiinflammatory effects through suppression of $\mathrm{T}$ cells, macrophages, monocytes, and NK cells ${ }^{[2-84]}$. PGE2 also favors Th2 humoral immune responses over Th1 cellular immune responses by inhibition of IL-2 synthesis and increased proliferation of Treg cells ${ }^{[85]}$. MSCs further suppress B and T cell proliferation through IDO and HLA-G, which contribute to DCs maturation and NK cell cytotoxicity ${ }^{[86,87]}$. Secretion of IL- 6 is another inhibitor of T-cell mediated immunity and directly disrupts the DC maturation process ${ }^{[88,89]}$. IL-6 also contributes to immune suppression by inhibiting apoptosis in lymphocytes and neutrophils. Lastly, MSCs can downregulate the immune response by suppressing macrophage polarization and generating tolerogenic DCs ${ }^{[78]}$.

In addition to immune suppression, MSCs can trigger active tissue regeneration and remodeling. MSCs secrete a variety of autocrine (a substance produced by a cell which stimulates its own secretion) and paracrine factors that support regenerative processes including angiogenesis, tissue repair, and regeneration ${ }^{[58]}$. MSC secreted trophic factors that facilitate the regeneration of specific tissues, including growth factors [brain-derived neurotrophic factor (BDNF), glial cell-derived neurotrophic factor, EGF, FGF-2/-4/-7/-9/-17, HGF, IGF-1, NGF, and platelet-derived growth factor (PDGF)], cytokines (IFN- $\gamma$, TNF- $\alpha$, and IL- $1 \alpha / \beta,-2,-6,-8,-10,-12$, and -13 ), chemokines (various CCLs and C-X-C motif ligands), antiapoptotic and angiogenic factors (VEGF), facilitating the regeneration of specific tissues ${ }^{[62]}$. The wide range of immunomodulatory effects of MSCs, from decreasing inflammatory responses to enhancing cellular repair demonstrates implications for treatment of severe liver disease as well as treatment for acute and chronic rejection following liver transplants.

\section{ANTI-FIBROTIC AND ANTIOXIDANT PROPERTIES OF MSCS}

Hepatic fibrosis can occur through a multitude of mechanisms including chronic liver injury from toxins (alcohol, drugs), viral infection, or metabolic imbalances. Fibrosis is a defining feature of chronic inflammation and is characterized by disruption of normal ECM architecture. HSCs are the key cells in hepatic fibrosis. HSCs can be activated from quiescent, vitamin A - storing cells to proliferative, $\alpha$-SMApositive, myofibroblast-like cells with increased collagen synthesis ${ }^{[20]}$. MSCs have been reported in various animal models of heart, liver, kidney, lungs, pancreas, skin, peritoneum, and rectum to have anti-fibrotic activity $^{[00]}$. 
MSCs are effective in treating fibrosis due to their antifibrotic and immunosuppressive properties. MSCs can upregulate the expression of MMP-2, $-9,-13$, and $-14^{[6,91,92]}$ which have recently been shown to reduce liver fibrosis by degrading $\mathrm{ECM}^{[60]}$. MSCs further augment this effect by downregulating the TIMP ${ }^{[93]}$. The balancing of MMPs and TIMP is associated with resolution of fibrosis ${ }^{[91]}$. MSCs also directly and indirectly suppress the activation and proliferation of HSCs, and thereby collagen synthesis. The direct interaction of MSCs with HSCs serves to suppress HSC proliferation by arresting them in Go/G1 phase through the inhibition of phosphorylation of extracellular signal-regulated kinase (ERK) $1 / 2^{[59]}$. When MSCs are directly co-cultured with HSCs, MSCs suppress the $\alpha$-SMA expression of HSCs, partially mediated by Notch pathway activation ${ }^{[94]}$. Indirectly, MSCs secrete trophic factors (IL-10, HGF, TGF-B3, and TNF- $\alpha$ ) that inhibit the proliferation of HSCs and decrease collagen synthesis ${ }^{[59,95]}$, while HGF and NGF promote the apoptosis of $\mathrm{HSCs}^{[59,95,96]}$. Additionally, MSCs promote the expansion of NK cell population in liver and peripheral blood ${ }^{[97]}$. Subsequently, NK cells have been found to inhibit HSC activation by direct killing through IFN- $\gamma$ and thus alleviate hepatic fibrosis ${ }^{[98]}$. This association was noted in rat models of cholestatic hepatic fibrosis where the intrahepatic NK cell levels were significantly decreased compared to control ${ }^{[97]}$. Furthermore, T regulatory (Treg) cells exert pro-fibrotic effects by inhibiting NK cells ${ }^{[99]}$. However, this effect is inhibited by MSCs immunomodulation of $\mathrm{T}$ cell proliferation and thus contributes to the antifibrotic effects of MSCs. Collectively, MSCs inhibit HSCs, and collagen synthesis, suppress overactive immune reactions and ultimately restrain fibrosis ${ }^{[59]}$.

Oxidative stress from reactive oxygen species (ROS) is a common mechanism of liver injury leading to liver fibrosis, cirrhosis, viral hepatitis, hepatocellular carcinoma (HCC), and others ${ }^{[100-104]}$. Several studies have suggested that MSCs mediate strong antioxidant effects in various animal models ${ }^{[105-108]}$. Carbon tetrachloride $(\mathrm{CCl} 4)$ and thioacetamide (TAA) are the most commonly used toxins to simulate oxidative liver damage $\mathrm{e}^{[109,110]}$. These toxins cause hepatocyte damage through lipid peroxidation, and alkylation of proteins, nucleic acids, and lipids ${ }^{[105,106,111]}$ leading to inflammation, hepatocellular damage, and fibrosis. Notably, the small amount of physiologic ROS produced by cellular respiration is necessary in cell signaling and homeostasis ${ }^{[112,113]}$. MSCs have demonstrated the capacity to alleviate $\mathrm{CCl} 4$ - and TAA-induced oxidative stress both in vitro and in vivo ${ }^{[105,107]}$. MSCs upregulate the expression of superoxide dismutase and induction of AREs, thus enhancing antioxidant and cytoprotective activity to reduce hepatocyte apoptosis ${ }^{[105,107]}$. MSCs' antioxidant effects have also been observed extra-hepatically in diseases such as dextran sulfate sodiuminduced colitis and neurodegenerative diseases (e.g., Friedreich's ataxia) ${ }^{[114]}$. The antioxidant effects of MSCs, combined with their immunomodulatory effects, are promising properties for the development of therapies to treat liver disease [Figure 1].

\section{CLINICAL APPLICATION OF MSC IN LIVER REGENERATION}

MSC-based cell therapy has multiple advantages over conventional liver transplantation or hepatectomies. MSCs are relatively easy to harvest from multiple different sources and they maintain their pluripotency following injection. A study by Kharaziha et al ${ }^{[115]}$ demonstrated that intravenous infusion of autologous bone marrow (BM)-derived MSCs among patients with decompensated cirrhosis resulted in statistically significant improvements in liver function, as measured by model for ESLD score (17.9-10.7), international normalized ratio (INR) (1.9-1.4), serum creatinine (114-80), serum albumin (30-33), and bilirubin (46-41) with no adverse events noted. Similarly, phase II clinical trials have shown similar results in alcoholic cirrhosis with histologic and quantitative improvement of hepatic fibrosis following MSC injection via hepatic artery ${ }^{[116,117]}$. The feasibility and safety of MSC transplantation is further supported by phase I studies showing improvements in liver function with MSC injection in liver disease of various causes with no noted adverse effects ${ }^{[118]}$. According to the National Institute of Health (NIH), there are currently 55 active clinical trials involving MSC-based therapy for liver disease of various etiology including cirrhosis, acute liver 


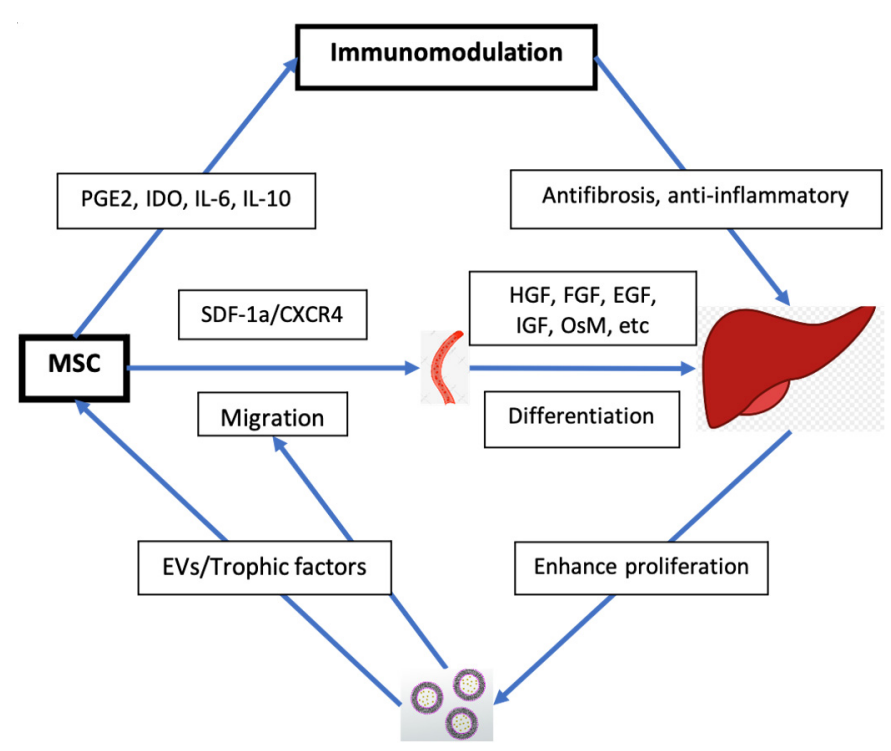

Figure 1. Therapeutic mechanisms of MSC in liver disease. MSC: Mesenchymal stem cell; PGE2: prostaglandin E2; IDO: dioxygenase; SDF-1a: stromal cell-derived factor-1a; CXCR4: CXC receptor 4; HGF: hepatocyte growth factor; FGF: fibroblast growth factor; EGF: epidermal growth factor; IGF: insulin-like growth factor; OsM: oncostatin M; EVs: extracellular vesicles.

failure, and hepatitis ${ }^{[119]}$. The MSCs used in these trials are derived from various sources including bone marrow, umbilical cord, adipose tissue, and menstrual blood. Most studies are using allogenic cell transplantation through peripheral veins, but there are cases of hepatic artery or portal vein injections. In multiple phase II studies of chronic hepatitis B and C, treatment with HSC vs. standard supportive treatment showed significant improvement in Child-Pugh and MELD scores ${ }^{[27,120,121]}$. In chronic hepatitis B patients, MSC infusion resulted in improved ascites and fibrosis markers as well as MELD scores ${ }^{[122]}$. MSC also appeared to be more effective when administered via portal vein than peripherally ${ }^{[120]}$. There was no significant difference in improvements between direct MSC injection compared to pre-differentiation of MSC to hepatocyte-like cells before transplantation ${ }^{[27]}$ [Table 4].

\section{ADMINISTRATION AND DOSING OF MSC-BASED THERAPY}

MSCs were first isolated from bone marrow $(B M)$ in $1970^{[127]}$. Since then, MSCs have been found in various tissues including adipose tissue, UC (Umbilical Cord blood), peripheral blood, synovial membranes, muscle, dermis, liver, and many others ${ }^{[13-17]}$. There is no established standard for procurement of MSCs for the treatment of liver disease, but they are most often harvested from the UC or BM because these are the most well studied ${ }^{[128]}$. Between BM-derived MSCs and UC-derived MSCs, UC-derived MSCs are the preferred cell type for multiple reasons. First, MSC-based treatment requires large amounts of MSCs and the UC provides significantly larger quantities of MSCs compared to $\mathrm{BM}^{[129,130]}$. Second, UC-derived MSCs can be isolated without the invasive procedures required for BM harvesting for MSCs ${ }^{[131]}$. Third, UC-derived MSCs are at an earlier phase of organic development compared to BM-derived MSCs, thus showing higher self-renewal and differentiation capacity ${ }^{[132]}$. Lastly, UC-derived MSCs have demonstrated lower immunogenicity than that of BM-derived MSCs suggesting superior allogeneic transplantation capability ${ }^{[133,134]}$.

Clinical trials have demonstrated various routes of administration for MSC-based liver therapy. The most common methods of administration were peripheral intravenous injection, followed by portal vein, hepatic artery, and intrasplenic injections ${ }^{[128]}$. Peripheral intravenous injection has an obvious advantage of 
Table 4. Summary of clinical trials with MSC for ESLD

\begin{tabular}{|c|c|c|c|c|}
\hline Clinical trial & MSC source & Route of administration & Dose & Disease \\
\hline Kharaziha et al. $^{[115]}$ & BM & Portal vein & $3 \times 10^{7}-5 \times 10^{7}$ cells & Chronic liver failure \\
\hline Amer et al. ${ }^{[120]}$ & BM & Intrasplenic and intrahepatic & $2 \times 10^{7}$ cells & End-stage liver failure \\
\hline Kantarcioglu et al. ${ }^{[123]}$ & BM & Peripheral vein & $1 \times 10^{6}$ cells $/ \mathrm{kg}$ & Liver cirrhosis \\
\hline Suk et al. ${ }^{[117]}$ & BM & Hepatic artery & $5 \times 10^{7}$ cells & Liver cirrhosis \\
\hline El-Ansary et al. ${ }^{[27]}$ & BM & Intrasplenic and peripheral vein & $1 \times 10^{6}$ cells & Chronic liver failure \\
\hline Mohamadnejad et al. ${ }^{[124]}$ & BM & Peripheral vein & $1.95 \times 10^{8}$ cells & Decompensated liver cirrhosis \\
\hline Yu et al. ${ }^{[125]}$ & UC & Peripheral vein & $5 \times 10^{7}-10 \times 10^{7}$ cells $/ \mathrm{kg}$ & HBV - decompensated liver cirrhosis \\
\hline Sakai et al. ${ }^{[126]}$ & Adipose & Hepatic artery & $3.3 \times 10^{5}-6.6 \times 10^{5} \mathrm{cell} / \mathrm{kg}$ & Liver cirrhosis \\
\hline
\end{tabular}

MSC: Mesenchymal stem cell; ESLD: end-stage liver disease; BM: bone marrow; UC: umbilical cord; HBV: hepatitis B virus.

convenience; however, animal models have demonstrated that $60 \%$ of the injected MSCs accumulated in the lungs and never reached the liver ${ }^{[135]}$. Similar results were seen with intravenously injected green fluorescent protein (GFP)-labeled MSCs in mice models. The GFP-labeled MSCs were found in high concentrations in the lung, but not the liver ${ }^{[136]}$. Interestingly, studies of miniature pigs with acute liver failure demonstrated restoration of hepatic function following intraportal injection of MSCs, but this effect was not seen in peripheral vein administration ${ }^{[137,138]}$. In a study comparing the administration of BM-derived MSCs through portal vein and intrasplenic injection for liver failure, results showed portal vein administration was more effective in improving model for end-stage liver disease (MELD) score compared to intrasplenic injection ${ }^{[120]}$. However, this difference was not seen after the first month of treatment. Based on these results, intraportal injection appears to be the best method; however, further research on the long-term recovery of hepatic function and occurrence of complications such as infection or venous thrombosis could help optimize the administration of MSC-based liver therapy.

The most effective dosing and frequency for MSC-based treatment of liver disease are unclear. Most clinical trials used a body-weight based dosing within the range $\left(0.5 \times 10^{6}-3 \times 10^{6}\right.$ cells $\left./ \mathrm{kg}\right)$ for a single dose, while some studies used total MSC quantity $\left(1 \times 10^{7}-20 \times 10^{7} \text { cells }\right)^{[128]}$. Studies have shown significant improvement of liver fibrosis with doses as low as $1 \times 10^{7} \mathrm{MSCs}^{[139]}$, and other studies demonstrated no improvement of liver fibrosis at a substantially higher dose of $2 \times 10^{8} \mathrm{MSCs}^{[124]}$. Most studies administered one-time doses, but in a study comparing a single dose to two doses a month apart, there was no significant difference in improvement of liver cirrhosis ${ }^{[117]}$. Further studies comparing a wider range of doses and frequencies are critical to generating an effective therapeutic dose.

\section{MSC PRIMING}

When MSCs are introduced to damaged liver, they can express various immune regulatory factors that can promote liver regeneration; examples of these include NO, PGE2, IDO, IL-6, IL-10, and HLA-G. However, depending on the concentration of inflammatory cytokines such as IFN- $\gamma$, TNF- $\alpha$, and IL-1 $\beta$, MSCs may lead to increased myofibroblast activity and worsen hepatic fibrosis ${ }^{[140,141]}$. In vitro MSC priming is one way to enhance the therapeutic effects, while limiting the unwanted pro-fibrotic properties. IFN- $\gamma$ primed MSCs induce IDO expression to inhibit the activation of $\mathrm{T}$ and $\mathrm{NK}$ cells ${ }^{[142]}$. The anti-inflammatory effect was increased when MSCs were primed with both IFN- $\gamma$ and TNF- $\alpha^{[143]}$. These cells were less susceptible to NK cell-mediated killing and had enhanced immunosuppression ${ }^{[144]}$. Additionally, MSC-based therapy has low efficiency partly due to poor cell survival following transplantation and priming can increase cell survival ${ }^{[145]}$. Zeaxanthin dipalmitate $(\mathrm{ZD})$ is a molecule that has been demonstrated to enhance the survivability of MSCs ${ }^{[146]}$. Pretreatment with ZD dramatically improved cell survival by suppressing apoptosis, inflammation, and ROS production in adipose-derived $\mathrm{MSCs}^{[146]}$. Further investigation is needed 
to determine whether the beneficial effects of priming MSCs prior to transplantation are maintained longterm after MSC differentiation.

\section{MSC-BASED CELL-FREE THERAPY}

MSCs secrete small extracellular vesicles, also known as exosomes, which contain proteins and factors that can exert specific actions on local and distant targets. MSC-derived EVs have been shown to reduce injury following myocardial ischemia, acute kidney injury, and acute liver failure but its mechanism of hepatoprotective effects is unclear ${ }^{[73]}$. In $\mathrm{CCl} 4$ mice models, the administration of MSC-derived exosomes led to inhibition of collagen production, which reduced hepatic inflammation and fibrosis ${ }^{[73]}$. MSC-derived exosomes have shown therapeutic effects in setting of acute liver injury in various mouse models. Specifically they have been demonstrated to increase hepatocyte proliferation, upregulate liver regenerative genes, and increase production of proliferative proteins such as cyclin $\mathrm{D} 1, \mathrm{Bcl}-\mathrm{xL}$, and signal transducer and activator of transcription (STAT)-3 ${ }^{[72]}$. Intra-tumor administration of MSC-derived exosomes in vivo has been shown to significantly reduce tumor growth ${ }^{[147]}$.

Direct transplantation of MSCs has associated risks including tumorigenesis and fibrogenic potential that can raise concerns with MSC cell-based therapy. Given that multiple studies have suggested the therapeutic effects of MSCs are exerted through MSC-derived exosomes, an acellular approach may provide similar benefits of cell-based therapy with fewer risks. MSC-derived exosomes also have great potential to be an intracellular drug delivery vehicle. MSC exosome-shuttle therapy has been used in regenerative medicine following ischemic cardiac injury ${ }^{[42]}$. MSC-derived exosomes have also been used to deliver cytokines such as IFN- $\beta$, IFN- $\alpha 2 b$, tumor necrosis factor-related apoptosis inducing ligand (TRAIL), and IL- 12 for liver cancer therapy ${ }^{[148,149,150,151-153]}$. CXCR4-enriched exosomes have shown beneficial effects due to upregulation of protein kinase B (Akt) signaling pathway that promotes cell survival and angiogenesis ${ }^{[154,155]}$. Currently, studies involving MSC-derived exosome-based therapy for liver disease are limited in number. Additional research on the potential application of MSC-derived exosomes could provide a novel approach for treatment of cirrhosis, hepatocellular carcinoma, and hepatitis.

\section{GENETIC MODIFICATION OF MSCS}

MSC-based therapy for liver disease is limited by several factors such as low rates of cell survival, poor engraftment, and inefficient homing mechanisms. Fortunately, these limitations can be overcome through genetic modifications. A variety of pro-survival genes have been inserted into MSCs to prolong their survival in target organs. For example, overexpression of genes for heat shock protein (HSP)-20, (Akt), SDF-1 $\beta$, hypoxia-inducible factor (HIF)- $1 \alpha$, FGF-2, all increased cellular survival by providing protection from oxidative stress, ischemia, hypoxia, and apoptosis ${ }^{[156-160]}$. Additionally, SDF-1 and CXCR4 engineered MSCs exhibited efficient homing and engraftment leading to greater regeneration of multiple organs including the liver ${ }^{[50,161,162]}$. Decorin (DCN), an important component in ECM, has demonstrated antifibrotic effects in liver by facilitating ECM degradation. DCN-modified MSCs exerted strong protective effects against hepatic fibrosis by suppressing TGF- $\beta /$ Smad signaling ${ }^{[163]}$. Transplantation of urokinase-type plasminogen activator (uPA) in the MSC gene showed lower expression of $\alpha$-SMA, TGF- $\beta 1$, and collagen types I/III with increased expression of MMP-2, -3, -3, HGF, and proliferating cell nuclear antigen. The overall effect was suppression of hepatic fibrosis and improvement in liver function ${ }^{[164]}$. High levels of IL-10 secretion from MSCs were associated with improved liver regeneration. IL-10 gene transfer into MSCs used as novel treatment in rat liver fibrosis models demonstrated suppressed HSCs, improved liver histopathology, and increased liver function ${ }^{[165]}$. These studies suggest that genetic modification of MSCs has the potential to improve survival, targeting, and pro-regenerative capacities of MSCs. However, the potential tumorigenic effects of MSCs should be considered and safety of treatment should be evaluated 
before genetic modifications are implemented in treating liver disease.

\section{MSC-BASED TISSUE ENGINEERING}

A recently developed strategy to improve liver regeneration is through tissue engineering of 3D scaffolds. MSCs exhibit improved cell proliferation and hepatic differentiation into characteristic mature hepatocytes when cultured in $3 \mathrm{D}$ biomatrix scaffold compared to in $2 \mathrm{D}$ substrates ${ }^{[166]}$. In vitro synthesis of liver scaffold can be generated from natural ${ }^{[167]}$ and synthetic ${ }^{[168]}$ materials, fluid flow ${ }^{[169]}, 3 \mathrm{D}$ culture ${ }^{[168,169]}$, or $3 \mathrm{D}$ bioprinting ${ }^{[170-172]} .3 \mathrm{D}$ spheroid MSC cultures have been shown to improve the differentiation efficiency of MSCs and to enhance therapeutic potential ${ }^{[173,174]}$. Spheroid cultures of MSCs increased the expression of antifibrotic factors and had greater hepatoprotective effects when compared to 2D cultured MSCs. Uygun et al. ${ }^{[175]}$ demonstrated that a $3 \mathrm{D}$ architecture of decellularized liver could be re-cellularized in vitro by MSCs and maintain viability after transplantation. This implies a transplantable liver can be synthesized in vitro. Similar success was seen with hepatobiliary organoids that could survive in vivo while maintaining functionality of hepatic and biliary structures ${ }^{[176,177]}$. Several additional studies have had success with in vitro generation of liver organoid and subsequent transplantation with good functionality in vivo. These studies suggest that transplantation of liver organoids in the setting of acute liver failure may prolong survival ${ }^{[178,179]}$. More research would be required to directly compare the benefits of liver organoid therapy $v$. MSC-based cell therapy [Figure 2].

\section{RISKS OF MSC THERAPY}

Despite several clinical trials that have demonstrated the safety and efficacy of MSCs in liver diseases, it is important to note MSC therapy is not without risks. As discussed previously, MSCs have the ability to migrate to the liver and promote regeneration through immunosuppression, antifibrotic, and antioxidant effects. However, there are circumstances in which MSC may cause harm due to their fibrogenic potential. MSCs have fibrogenic potential when cultured in hepatogenic differentiation medium containing HGF, FGF-4, and OsM. When these MSCs were transplanted into the liver of NOD/SCID mice undergoing partial hepatectomy, they expressed $\alpha$-SMA, a marker for myofibroblast differentiation ${ }^{[140]}$. Additionally, transplanted MSCs in normal and acutely injured NOD/SCID mice models showed lower engraftment rates compared to chronically injured mice and greater number of MSCs in the acute liver injury models exhibited a myofibroblast-like morphology ${ }^{[141]}$. These results highlight the need for further evaluation of the potential contraindications of MSC therapy in the treatment of hepatic fibrosis.

The potential of MSCs for anti-tumor therapy stems from their ability to migrate and incorporate into tumor stroma ${ }^{[180]}$. There is conflicting evidence as to whether MSCs suppress tumor growth or contribute to tumor growth, through promotion of tumor-associated fibrosis, immunosuppression, angiogenesis, and metastasis ${ }^{[181]}$. Certainly, this poses a risk in MSC-based therapy for liver disease. Tumor cells secrete transforming growth factor (TGF)- $\beta$, which induce MSCs to preferentially differentiate into pro-fibrotic cells expressing $\alpha$-SMA, tenascin $C$, and fibroblast surface protein ${ }^{[181]}$. Additionally, the tumor microenvironment increases the secretion of growth-stimulating factors such as CCL5/RANTES and stromal cell-derived factor-1 (SDF-1) ${ }^{[180]}$. MSCs can promote proliferation of tumor cells by differentiation into carcinoma-associated fibroblasts or tumor-associated fibroblasts, which express $\alpha$-SMA, induce neovascularization and express tumor-stimulating factors ${ }^{[182,183]}$. Furthermore, MSCs exert antiapoptotic effects through factors including VEGF, FGF-2, HGF, BDNF, SDF-1 $\alpha$, IGF-1, and TGF- $\beta$ that can support tumor growth. This effect is compounded by hypoxia in the tumor microenvironment which stimulates increased production of pro-survival factors ${ }^{[184-187]}$. Genetic modification and pretreatment of MSCs may be effective in decreasing the fibrogenic and tumorigenic potential of MSCs and increasing the safety profile of MSC-based therapy. 


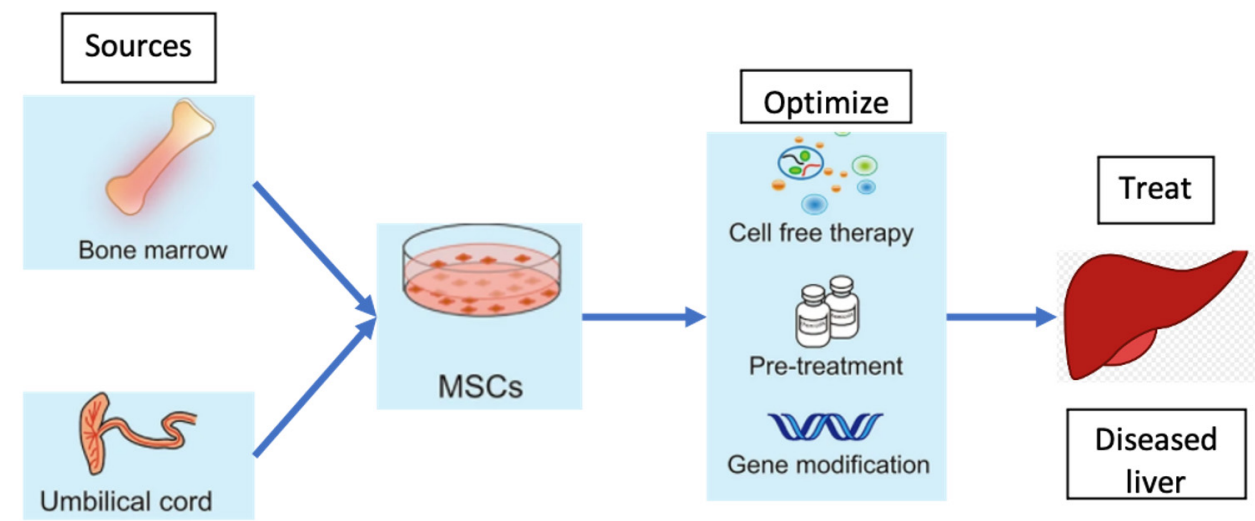

Figure 2. Treatment of liver disease with MSC-based therapy. MSCs: Mesenchymal stem cells.

\section{CONCLUSION}

Currently, liver transplantation is the only definitive treatment for end-stage liver disease. Although the global organ transplantation is expanding and transplantation outcomes are improving through advancements in immunosuppressive drugs and surgical techniques, there is still significant room for progress. MSC-based therapy may offer a chance for more patients to receive a potentially curative treatment. MSCs can migrate to damaged liver tissue, differentiate into hepatocyte-like cells, reduce inflammation, decrease fibrosis, and have antioxidant effects. Multiple clinical trials have verified the safety and efficacy of MSC therapy for severe liver diseases of various etiologies including cirrhosis, liver failure, and post-transplant complications. Further studies with larger samples and blinded trials need to be conducted before MSCs can become an accepted alternative to liver transplant. Additionally, more clinical trials are necessary for optimizing MSC injection routes, dosing, frequency, and mechanism of delivery. Future studies on MSC priming, homing mechanism, MSC derived exosome therapy, genetic modifications, and tissue engineering could greatly improve MSC therapy and may create novel approaches to treating end-stage liver disease.

\section{DECLARATIONS}

\section{Authors' contributions}

Made substantial contributions to conception and writing of this paper and performed extensive literature review and interpretations: Lee SM, Lee SD, Wang SZ, Levy MF

Made contributions by providing comments and feedback throughout the writing of this paper: Sarkar D, Lee HM, Khan A, Bhati C, Sharma A, Kumaran V, Bruno D, Cotterell A

\section{Availability of data and materials}

Not applicable.

\section{Financial support and sponsorship}

None.

\section{Conflicts of interest}

All authors declared that there are no conflicts of interest.

\section{Ethical approval and consent to participate}

Not applicable. 


\section{Consent for publication}

Not applicable.

\section{Copyright}

(c) The Author(s) 2021.

\section{REFERENCES}

1. Perugorria MJ, Olaizola P, Banales JM. Cholangiocyte-to-hepatocyte differentiation: a context - dependent process and an opportunity for regenerative medicine. Hepatology 2019;69:480-3. DOI PubMed

2. Michalopoulos GK. Principles of liver regeneration and growth homeostasis. Compr Physiol 2013;3:485-513. DOI PubMed

3. Fujii H, Hirose T, Oe S, et al. Contribution of bone marrow cells to liver regeneration after partial hepatectomy in mice. $J$ Hepatol 2002;36:653-659. DOI PubMed

4. Michalopoulos GK, Khan Z. Liver stem cells: experimental findings and implications for human liver disease. Gastroenterology 2015;149:876-82. DOI PubMed PMC

5. Jiang JX, Török NJ. Liver injury and the activation of the hepatic myofibroblasts. Curr Pathobiol Rep 2013;1:215-23. DOI PubMed PMC

6. Cordero-Espinoza L, Huch M. The balancing act of the liver: tissue regeneration versus fibrosis. J Clin Invest 2018;128:85-96. DOI PubMed PMC

7. Xu J, Kisseleva T. Bone marrow-derived fibrocytes contribute to liver fibrosis. Exp Biol Med 2015;240:691-700. DOI PubMed PMC

8. Bellini A, Mattoli S. The role of the fibrocyte, a bone marrow-derived mesenchymal progenitor, in reactive and reparative fibroses. Lab Invest 2007;87:858-70. DOI PubMed

9. Ling C, Nishimoto K, Rolfs Z, Smith LM, Frey BL, Welham NV. Differentiated fibrocytes assume a functional mesenchymal phenotype with regenerative potential. Sci Adv 2019;5:eaav7384. DOI PubMed PMC

10. Markets R and. Global Organ Transplantation Market Review 2014-2019 - Forecast to 2024. Available from: https://www.prnewswire.com/news-releases/global-organ-transplantation-market-review-2014-2019---forecast-to-2024300952739.html. [Last accessed on 20 Apr 2021].

11. Lange C, Bassler P, Lioznov M-V, et al. Liver-specific gene expression in mesenchymal stem cells is induced by liver cells. World $J$ Gastroenterol 2005;11:4497-504. DOI PubMed PMC

12. Ong S-Y, Dai H, Leong KW. Inducing hepatic differentiation of human mesenchymal stem cells in pellet culture. Biomaterials 2006;27:4087-97. DOI PubMed

13. Campagnoli C, Roberts IA, Kumar S, Bennett PR, Bellantuono I, Fisk NM. Identification of mesenchymal stem/progenitor cells in human first-trimester fetal blood, liver, and bone marrow. Blood 2001;98:2396-402. DOI PubMed

14. De Ugarte DA, Morizono K, Elbarbary A, et al. Comparison of multi-lineage cells from human adipose tissue and bone marrow. Cells Tissues Organs 2003;174:101-9. DOI PubMed

15. Erices A, Conget P, Minguell JJ. Mesenchymal progenitor cells in human umbilical cord blood. Br J Haematol 2000;109:235-42. DOI PubMed

16. Jiang Y, Vaessen B, Lenvik T, Blackstad M, Reyes M, Verfaillie CM. Multipotent progenitor cells can be isolated from postnatal murine bone marrow, muscle, and brain. Exp Hematol 2002;30:896-904. DOI PubMed

17. Zvaifler NJ, Marinova-Mutafchieva L, Adams G, et al. Mesenchymal precursor cells in the blood of normal individuals. Arthritis Res 2000;2:477-88. DOI PubMed PMC

18. Bernardo ME, Cometa AM, Pagliara D, et al. Ex vivo expansion of mesenchymal stromal cells. Best Pract Res Clin Haematol 2011;24:73-81. DOI PubMed

19. Chapel A, Bertho JM, Bensidhoum M, et al. Mesenchymal stem cells home to injured tissues when co-infused with hematopoietic cells to treat a radiation-induced multi-organ failure syndrome. J Gene Med 2003;5:1028-38. DOI PubMed

20. Eom YW, Shim KY, Baik SK. Mesenchymal stem cell therapy for liver fibrosis. Korean J Intern Med 2015;30:580-9. DOI PubMed PMC

21. Forbes SJ, Gupta S, Dhawan A. Cell therapy for liver disease: From liver transplantation to cell factory. J Hepatol 2015;62:S157-69. DOI PubMed

22. Av P, Ia V. Expression of early hematopoietic markers in cord blood and mobilized blood. Tsitologiia 2012;54:774-82. PubMed

23. Martinez-Agosto JA, Mikkola HKA, Hartenstein V, Banerjee U. The hematopoietic stem cell and its niche: a comparative view. Genes Dev 2007;21:3044-3060. DOI PubMed

24. Mizukoshi E, Kaneko S. Immune cell therapy for hepatocellular carcinoma. J Hematol Oncol 2019;12:52. DOI PubMed PMC

25. Asahara T, Murohara T, Sullivan A, et al. Isolation of putative progenitor endothelial cells for angiogenesis. Science 1997;275:964-6. DOI PubMed

26. Kaushal S, Amiel GE, Guleserian KJ, et al. Functional small-diameter neovessels created using endothelial progenitor cells expanded ex vivo. Nat Med 2001;7:1035-40. DOI PubMed PMC

27. El-Ansary M, Abdel-Aziz I, Mogawer S, et al. Phase II trial: undifferentiated versus differentiated autologous mesenchymal stem cells transplantation in Egyptian patients with HCV induced liver cirrhosis. Stem Cell Rev Rep 2012;8:972-81. DOI PubMed 
28. Satija NK, Singh VK, Verma YK, et al. Mesenchymal stem cell-based therapy: a new paradigm in regenerative medicine. J Cell Mol Med 2009;13:4385-402. DOI PubMed PMC

29. Dominici M, Blanc KL, Mueller I, et al. Minimal criteria for defining multipotent mesenchymal stromal cells. The International Society for Cellular Therapy position statement. Cytotherapy 2006;8:315-7. DOI PubMed

30. Huang L, Zhang C, Gu J, et al. A randomized, placebo-controlled trial of human umbilical cord blood mesenchymal stem cell infusion for children with cerebral palsy. Cell Transplant 2018;27:325-34. DOI PubMed PMC

31. Chamberlain G, Fox J, Ashton B, Middleton J. Concise review: mesenchymal stem cells: their phenotype, differentiation capacity, immunological features, and potential for homing. Stem Cell 2007;25:2739-49. DOI PubMed

32. Sordi V, Malosio ML, Marchesi F, et al. Bone marrow mesenchymal stem cells express a restricted set of functionally active chemokine receptors capable of promoting migration to pancreatic islets. Blood 2005;106:419-27. DOI PubMed

33. Ullah M, Liu DD, Thakor AS. Mesenchymal stromal cell homing: mechanisms and strategies for improvement. iScience 2019;15:421-38. DOI PubMed PMC

34. Xiang G, Zhang G, Fang C, Gao P, Chen K. A preliminary study of the homing capacity of allograft mesenchymal stem cells to rat liver. Di Yi Jun Yi Da Xue Xue Bao 2005;25:994-7. PubMed

35. Gao J, Dennis JE, Muzic RF, Lundberg M, Caplan AI. The dynamic in vivo distribution of bone marrow-derived mesenchymal stem cells after infusion. Cells Tissues Organs ;169:12-20. DOI PubMed

36. Wojakowski W, Tendera M, Michałowska A, et al. Mobilization of CD34/CXCR4+, CD34/CD117+, c-met+ stem cells, and mononuclear cells expressing early cardiac, muscle, and endothelial markers into peripheral blood in patients with acute myocardial infarction. Circulation 2004;110:3213-20. DOI PubMed

37. Bowie MB, McKnight KD, Kent DG, McCaffrey L, Hoodless PA, Eaves CJ. Hematopoietic stem cells proliferate until after birth and show a reversible phase-specific engraftment defect. J Clin Invest 2006;116:2808-16. DOI PubMed PMC

38. Gordon MY, Levicar N, Pai M, et al. Characterization and clinical application of human CD34+ stem/progenitor cell populations mobilized into the blood by granulocyte colony-stimulating factor. Stem Cells 2006;24:1822-30. DOI PubMed

39. Kollet O, Shivtiel S, Chen Y-Q, et al. HGF, SDF-1, and MMP-9 are involved in stress-induced human CD34+ stem cell recruitment to the liver. J Clin Invest 2003;112:160-9. DOI PubMed PMC

40. Jin DK, Shido K, Kopp H-G, et al. Cytokine-mediated deployment of SDF-1 induces revascularization through recruitment of CXCR4+ hemangiocytes. Nat Med 2006;12:557-67. DOI PubMed PMC

41. Petit I, Jin D, Rafii S. The SDF-1-CXCR4 signaling pathway: a molecular hub modulating neo-angiogenesis. Trends Immunol 2007;28:299-307. DOI PubMed PMC

42. Tang YL, Zhu W, Cheng M, et al. Hypoxic preconditioning enhances the benefit of cardiac progenitor cell therapy for treatment of myocardial infarction by inducing CXCR4 expression. Circ Res 2009;104:1209-16. DOI PubMed PMC

43. Horuk R. Chemokines beyond inflammation. Nature 1998;393:524-5. DOI PubMed

44. Kahn J, Byk T, Jansson-Sjostrand L, et al. Overexpression of CXCR4 on human CD34+ progenitors increases their proliferation, migration, and NOD/SCID repopulation. Blood 2004;103:2942-9. DOI PubMed

45. Liu H, Liu S, Li Y, et al. The role of SDF-1-CXCR4/CXCR7 axis in the therapeutic effects of hypoxia-preconditioned mesenchymal stem cells for renal ischemia/reperfusion injury. PloS One 2012;7:e34608. DOI PubMed PMC

46. Zhang D, Fan GC, Zhou X, et al. Over-expression of CXCR4 on mesenchymal stem cells augments myoangiogenesis in the infarcted myocardium. J Mol Cell Cardiol 2008;44:281-92. DOI PubMed PMC

47. Lei Y, Liu Z, Han Q, Kang W, Zhang L, Lou S. G-CSF enhanced SDF-1 gradient between bone marrow and liver associated with mobilization of peripheral blood CD34+ cells in rats with acute liver failure. Dig Dis Sci 2010;55:285-91. DOI PubMed

48. Ma HC, Shi XL, Ren HZ, Yuan XW, Ding YT. Targeted migration of mesenchymal stem cells modified with CXCR4 to acute failing liver improves liver regeneration. World J Gastroenterol 2014;20:14884-94. DOI PubMed PMC

49. Wynn RF, Hart CA, Corradi-Perini C, et al. A small proportion of mesenchymal stem cells strongly expresses functionally active CXCR4 receptor capable of promoting migration to bone marrow. Blood 2004;104:2643-5. DOI PubMed

50. Du Z, Wei C, Yan J, et al. Mesenchymal stem cells overexpressing C-X-C chemokine receptor type 4 improve early liver regeneration of small-for-size liver grafts. Liver Transpl 2013;19:215-25. DOI PubMed

51. Schwartz RE, Reyes M, Koodie L, et al. Multipotent adult progenitor cells from bone marrow differentiate into functional hepatocytelike cells. J Clin Invest 2002;109:1291-302. DOI PubMed PMC

52. Zhang GZ, Sun HC, Zheng LB, Guo JB, Zhang XL. In vivo hepatic differentiation potential of human umbilical cord-derived mesenchymal stem cells: therapeutic effect on liver fibrosis/cirrhosis. World J Gastroenterol 2017;23:8152-68. DOI PubMed PMC

53. Sato Y, Araki H, Kato J, et al. Human mesenchymal stem cells xenografted directly to rat liver are differentiated into human hepatocytes without fusion. Blood 2005;106:756-63. DOI PubMed

54. Dai LJ, Li HY, Guan LX, Ritchie G, Zhou JX. The therapeutic potential of bone marrow-derived mesenchymal stem cells on hepatic cirrhosis. Stem Cell Res 2009;2:16-25. DOI PubMed

55. Yan Y, Xu W, Qian H, et al. Mesenchymal stem cells from human umbilical cords ameliorate mouse hepatic injury in vivo. Liver Int 2009;29:356-65. DOI PubMed

56. Jang YY, Collector MI, Baylin SB, Diehl AM, Sharkis SJ. Hematopoietic stem cells convert into liver cells within days without fusion. Nat Cell Biol 2004;6:532-9. DOI PubMed

57. Chen L, Zhang C, Chen L, et al. Human menstrual blood-derived stem cells ameliorate liver fibrosis in mice by targeting hepatic stellate cells via paracrine mediators. STEM CELLS Transl Med 2017;6:272-84. DOI PubMed PMC

58. Skalnikova H. Proteomic techniques for characterisation of mesenchymal stem cell secretome. Biochimie 2013;95:2196-211. DOI 
PubMed

59. Wang J, Bian C, Liao L, et al. Inhibition of hepatic stellate cells proliferation by mesenchymal stem cells and the possible mechanisms. Hepatol Res 2009;39:1219-28. DOI PubMed

60. Rabani V, Shahsavani M, Gharavi M, Piryaei A, Azhdari Z, Baharvand H. Mesenchymal stem cell infusion therapy in a carbon tetrachloride-induced liver fibrosis model affects matrix metalloproteinase expression. Cell Biol Int 2010;34:601-5. DOI PubMed

61. Sakaida I, Terai S, Yamamoto N, et al. Transplantation of bone marrow cells reduces CCl4-induced liver fibrosis in mice. Hepatology 2004;40:1304-11. DOI PubMed

62. Wang L, Wang X, Wang L, et al. Hepatic vascular endothelial growth factor regulates recruitment of rat liver sinusoidal endothelial cell progenitor cells. Gastroenterology 2012;143:1555-63.e2. DOI PubMed PMC

63. Kim SU, Oh HJ, Wanless IR, Lee S, Han K-H, Park YN. The Laennec staging system for histological sub-classification of cirrhosis is useful for stratification of prognosis in patients with liver cirrhosis. J Hepatol 2012;57:556-63. DOI PubMed

64. Gorji S, Karimpor Malekshah AA, Hashemi-Soteh MB, Rafiei A, Parivar K, Aghdami N. Effect of mesenchymal stem cells on Doxorubicin-induced fibrosis. Cell J 2012;14:142-51. PubMed PMC

65. Zhang D, Jiang M, Miao D. Transplanted human amniotic membrane-derived mesenchymal stem cells ameliorate carbon tetrachloride-induced liver cirrhosis in mouse. PloS One 2011;6:e16789. DOI PubMed PMC

66. Michalopoulos GK. Liver regeneration after partial hepatectomy: critical analysis of mechanistic dilemmas. Am J Pathol 2010;176:213. DOI PubMed PMC

67. Marsden ER, Hu Z, Fujio K, Nakatsukasa H, Thorgeirsson SS, Evarts RP. Expression of acidic fibroblast growth factor in regenerating liver and during hepatic differentiation. Lab Invest 1992;67:427-33. PubMed

68. Webber EM, Godowski PJ, Fausto N. In vivo response of hepatocytes to growth factors requires an initial priming stimulus. Hepatology 1994;19:489-97. PubMed

69. Nozawa K, Kurumiya Y, Yamamoto A, Isobe Y, Suzuki M, Yoshida S. Up-regulation of telomerase in primary cultured rat hepatocytes. J Biochem 1999;126:361-7. DOI PubMed

70. $\mathrm{Li} \mathrm{W}-\mathrm{L}, \mathrm{Su}$ J, Yao Y-C, et al. Isolation and characterization of bipotent liver progenitor cells from adult mouse. Stem Cells 2006;24:322-32. DOI PubMed

71. Wang J, Cen P, Chen J, et al. Role of mesenchymal stem cells, their derived factors, and extracellular vesicles in liver failure. Stem Cell Res Ther 2017;8:137. DOI PubMed PMC

72. Tan CY, Lai RC, Wong W, Dan YY, Lim S-K, Ho HK. Mesenchymal stem cell-derived exosomes promote hepatic regeneration in drug-induced liver injury models. Stem Cell Res Ther 2014;5:76. DOI PubMed PMC

73. Li T, Yan Y, Wang B, et al. Exosomes derived from human umbilical cord mesenchymal stem cells alleviate liver fibrosis. Stem Cells Dev 2012;22:845-54. DOI PubMed PMC

74. Robbins PD, Morelli AE. Regulation of immune responses by extracellular vesicles. Nat Rev Immunol 2014;14:195-208. DOI PubMed PMC

75. Zhang B, Yin Y, Lai RC, Tan SS, Choo ABH, Lim SK. Mesenchymal stem cells secrete immunologically active exosomes. Stem Cells Dev 2014;23:1233-44. DOI PubMed

76. Weiss ARR, Dahlke MH. Immunomodulation by mesenchymal stem cells (MSCs): mechanisms of action of living, apoptotic, and dead MSCs. Front Immunol 2019;10:1191. DOI PubMed PMC

77. De Miguel MP, Fuentes-Julián S, Blázquez-Martínez A, et al. Immunosuppressive properties of mesenchymal stem cells: advances and applications. Curr Mol Med 2012;12:574-91. DOI PubMed

78. Sato K, Ozaki K, Oh I, et al. Nitric oxide plays a critical role in suppression of T-cell proliferation by mesenchymal stem cells. Blood 2007;109:228-34. DOI PubMed

79. Wang D, Mann JR, DuBois RN. The role of prostaglandins and other eicosanoids in the gastrointestinal tract. Gastroenterology 2005;128:1445-61. DOI PubMed

80. Breyer RM, Bagdassarian CK, Myers SA, Breyer MD. Prostanoid receptors: subtypes and signaling. Annu Rev Pharmacol Toxicol 2001;41:661-90. DOI PubMed

81. Samuelsson B, Morgenstern R, Jakobsson PJ. Membrane prostaglandin E synthase-1: a novel therapeutic target. Pharmacol Rev 2007;59:207-24. DOI PubMed

82. Spaggiari GM, Abdelrazik H, Becchetti F, Moretta L. MSCs inhibit monocyte-derived DC maturation and function by selectively interfering with the generation of immature DCs: central role of MSC-derived prostaglandin E2. Blood 2009;113:6576-83. DOI PubMed

83. Linnemeyer PA, Pollack SB. Prostaglandin E2-induced changes in the phenotype, morphology, and lytic activity of IL-2-activated natural killer cells. J Immunol 1993;150:3747-54. PubMed

84. Yakar I, Melamed R, Shakhar G, et al. Prostaglandin e(2) suppresses NK activity in vivo and promotes postoperative tumor metastasis in rats. Ann Surg Oncol 2003;10:469-79. DOI PubMed

85. Wang X, Willenbring H, Akkari Y, et al. Cell fusion is the principal source of bone-marrow-derived hepatocytes. Nature 2003;422:897-901. DOI PubMed

86. Volarevic V, Al-Qahtani A, Arsenijevic N, Pajovic S, Lukic ML. Interleukin-1 receptor antagonist (IL-1Ra) and IL-1Ra producing mesenchymal stem cells as modulators of diabetogenesis. Autoimmunity 2010;43:255-63. DOI PubMed

87. Parekkadan B, van Poll D, Suganuma K, et al. Mesenchymal stem cell-derived molecules reverse fulminant hepatic failure. PloS One 2007;2:e941. DOI PubMed PMC

88. Djouad F, Charbonnier L-M, Bouffi C, et al. Mesenchymal stem cells inhibit the differentiation of dendritic cells through an 
interleukin-6-dependent mechanism. Stem Cells 2007;25:2025-32. DOI PubMed

89. Jiang X-X, Zhang Y, Liu B, et al. Human mesenchymal stem cells inhibit differentiation and function of monocyte-derived dendritic cells. Blood 2005;105:4120-6. DOI PubMed

90. Usunier B, Benderitter M, Tamarat R, Chapel A. Management of fibrosis: the mesenchymal stromal cells breakthrough. Stem Cells Int 2014;2014:340257. DOI PubMed PMC

91. Semedo P, Correa-Costa M, Antonio Cenedeze M, et al. Mesenchymal stem cells attenuate renal fibrosis through immune modulation and remodeling properties in a rat remnant kidney model. Stem Cells 2009;27:3063-73. DOI PubMed

92. Wu Y, Huang S, Enhe J, et al. Bone marrow-derived mesenchymal stem cell attenuates skin fibrosis development in mice. Int Wound J 2014;11:701-10. DOI PubMed

93. Ali G, Mohsin S, Khan M, et al. Nitric oxide augments mesenchymal stem cell ability to repair liver fibrosis. $J$ Transl Med 2012;10:75. DOI PubMed PMC

94. Chen S, Xu L, Lin N, Pan W, Hu K, Xu R. Activation of Notch1 signaling by marrow-derived mesenchymal stem cells through cellcell contact inhibits proliferation of hepatic stellate cells. Life Sci 2011;89:975-81. DOI PubMed

95. Parekkadan B, van Poll D, Megeed Z, et al. Immunomodulation of activated hepatic stellate cells by mesenchymal stem cells. Biochem Biophys Res Commun 2007;363:247-52. DOI PubMed PMC

96. Lin N, Hu K, Chen S, et al. Nerve growth factor-mediated paracrine regulation of hepatic stellate cells by multipotent mesenchymal stromal cells. Life Sci 2009;85:291-5. DOI PubMed

97. Duman DG, Zibandeh N, Ugurlu MU, et al. Mesenchymal stem cells suppress hepatic fibrosis accompanied by expanded intrahepatic natural killer cells in rat fibrosis model. Mol Biol Rep 2019;46:2997-3008. DOI PubMed

98. Gao B, Radaeva S. Natural killer and natural killer T cells in liver fibrosis. Biochim Biophys Acta 2013;1832:1061-9. DOI PubMed PMC

99. Singer NG, Caplan AI. Mesenchymal stem cells: mechanisms of inflammation. Annu Rev Pathol 2011;6:457-78. DOI PubMed

100. Clément S, Pascarella S, Negro F. Hepatitis C virus infection: molecular pathways to steatosis, insulin resistance and oxidative stress. Viruses 2009;1:126-43. DOI PubMed PMC

101. Tanikawa K, Torimura T. Studies on oxidative stress in liver diseases: important future trends in liver research. Med Mol Morphol 2006;39:22-7. DOI PubMed

102. Ivanov AV, Smirnova OA, Ivanova ON, Masalova OV, Kochetkov SN, Isaguliants MG. Hepatitis C virus proteins activate NRF2/ARE pathway by distinct ROS-dependent and independent mechanisms in HUH7 cells. PloS One 2011;6:e24957. DOI PubMed PMC

103. Zhu R, Wang Y, Zhang L, Guo Q. Oxidative stress and liver disease. Hepatol Res 2012;42:741-9. DOI PubMed

104. Cash WJ, McCance DR, Young IS, et al. Primary biliary cirrhosis is associated with oxidative stress and endothelial dysfunction but not increased cardiovascular risk. Hepatol Res 2010;40:1098-106. DOI PubMed

105. Cho K-A, Woo S-Y, Seoh J-Y, Han H-S, Ryu K-H. Mesenchymal stem cells restore CCl4-induced liver injury by an antioxidative process. Cell Biol Int 2012;36:1267-74. DOI PubMed

106. Parola M, Robino G. Oxidative stress-related molecules and liver fibrosis. J Hepatol 2001;35:297-306. DOI PubMed

107. Quintanilha LF, Takami T, Hirose Y, et al. Canine mesenchymal stem cells show antioxidant properties against thioacetamideinduced liver injury in vitro and in vivo. Hepatol Res 2014;44:E206-17. DOI PubMed

108. Ayatollahi M, Hesami Z, Jamshidzadeh A, Gramizadeh B. Antioxidant effects of bone marrow mesenchymal stem cell against carbon tetrachloride-induced oxidative damage in rat livers. Int J Organ Transplant Med 2014;5:166-73. PubMed PMC

109. Ledda-Columbano GM, Coni P, Curto M, et al. Induction of two different modes of cell death, apoptosis and necrosis, in rat liver after a single dose of thioacetamide. Am J Pathol 1991;139:1099-109. PubMed PMC

110. Li X, Benjamin IS, Alexander B. Reproducible production of thioacetamide-induced macronodular cirrhosis in the rat with no mortality. J Hepatol 2002;36:488-93. DOI PubMed

111. Weber LWD, Boll M, Stampfl A. Hepatotoxicity and mechanism of action of haloalkanes: carbon tetrachloride as a toxicological model. Crit Rev Toxicol 2003;33:105-36. DOI PubMed

112. Joyeux M, Rolland A, Fleurentin J, Mortier F, Dorfman P. tert-Butyl hydroperoxide-induced injury in isolated rat hepatocytes: a model for studying anti-hepatotoxic crude drugs. Planta Med 1990;56:171-4. DOI PubMed

113. Devasagayam TPA, Tilak JC, Boloor KK, Sane KS, Ghaskadbi SS, Lele RD. Free radicals and antioxidants in human health: current status and future prospects. J Assoc Physicians India 2004;52:794-804. PubMed

114. Dey R, Kemp K, Gray E, Rice C, Scolding N, Wilkins A. Human mesenchymal stem cells increase anti-oxidant defences in cells derived from patients with Friedreich's ataxia. Cerebellum 2012;11:861-71. DOI PubMed

115. Kharaziha P, Hellström PM, Noorinayer B, et al. Improvement of liver function in liver cirrhosis patients after autologous mesenchymal stem cell injection: a phase I-II clinical trial. Eur J Gastroenterol Hepatol 2009;21:1199-205. DOI PubMed

116. Jang YO, Kim YJ, Baik SK, et al. Histological improvement following administration of autologous bone marrow-derived mesenchymal stem cells for alcoholic cirrhosis: a pilot study. Liver Int 2014;34:33-41. DOI PubMed

117. Suk KT, Yoon J-H, Kim MY, et al. Transplantation with autologous bone marrow-derived mesenchymal stem cells for alcoholic cirrhosis: Phase 2 trial. Hepatology 2016;64:2185-97. DOI PubMed

118. Alimoghaddam K, Mohamadnejad M, Bonab MM, et al. 106: Phase 1 Trial of autologous bone marrow mesenchymal stem cell transplantation in patients with decompensated liver cirrhosis. Biol Blood Marrow Transplant 2008;14:41. DOI

119. Liver Diseases and Mesenchymal Stem Cells - List Results. Home - ClinicalTrials.gov, US National Library of Medicine, NIH. Available from: clinicaltrials.gov/ct2/results?cond=Liver+Diseases. [Last accessed on 12 Jul 2021]. 
120. Amer M-EM, El-Sayed SZ, El-Kheir WA, et al. Clinical and laboratory evaluation of patients with end-stage liver cell failure injected with bone marrow-derived hepatocyte-like cells. Eur J Gastroenterol Hepatol 2011;23:936-41. DOI PubMed

121. Xue H-L, Zeng W-Z, Wu X-L, et al. Clinical therapeutic effects of human umbilical cord-derived mesenchymal stem cells transplantation in the treatment of end-stage liver disease. Transplant Proc 2015;47:412-8. DOI PubMed

122. PT. Prodia Stem Cell Indonesia. Umbilical Cord Mesenchymal Stem Cell for Liver Cirrhosis Patient Caused by Hepatitis B: Phase I/ II Study. clinicaltrials.gov; 2020. Available from: https://clinicaltrials.gov/ct2/show/NCT04357600. [Last accessed on 20 Apr 2021 ].

123. Kantarcioglu M. Efficacy of Exvivo Expanded Autologous Mesenchymal Stem Cell Transplantation Via Peripheral Vein in Patients With Liver Cirrhosis. clinicaltrials.gov; 2012. Available from: https://clinicaltrials.gov/ct2/show/NCT01499459. [Last accessed on 20 Apr 2021].

124. Mohamadnejad M, Alimoghaddam K, Bagheri M, et al. Randomized placebo-controlled trial of mesenchymal stem cell transplantation in decompensated cirrhosis. Liver Int 2013;33:1490-6. DOI PubMed

125. Yu SJ, Chen LM, Lyu S, et al. Safety and efficacy of human umbilical cord derived-mesenchymal stem cell transplantation for treating patients with HBV-related decompensated cirrhosis. Zhonghua Gan Zang Bing Za Zhi 2016;24:51-5. DOI PubMed

126. Sakai Y, Takamura M, Seki A, et al. Phase I clinical study of liver regenerative therapy for cirrhosis by intrahepatic arterial infusion of freshly isolated autologous adipose tissue-derived stromal/stem (regenerative) cell. Regen Ther 2017;6:52-64. DOI PubMed PMC

127. Friedenstein AJ, Chailakhjan RK, Lalykina KS. The development of fibroblast colonies in monolayer cultures of guinea-pig bone marrow and spleen cells. Cell Prolif 1970;3:393-403. DOI PubMed

128. Yang X, Meng Y, Han Z, Ye F, Wei L, Zong C. Mesenchymal stem cell therapy for liver disease: full of chances and challenges. Cell Biosci 2020;10:123. DOI PubMed PMC

129. Batsali AK, Kastrinaki MC, Papadaki HA, Pontikoglou C. Mesenchymal stem cells derived from Wharton's jelly of the umbilical cord: biological properties and emerging clinical applications. Curr Stem Cell Res 2013;8:144-55. DOI PubMed

130. Mueller SM, Glowacki J. Age-related decline in the osteogenic potential of human bone marrow cells cultured in three-dimensional collagen sponges. $J$ Cell Biochem 2001;82:583-90. DOI PubMed

131. Lu LL, Liu YJ, Yang SG, et al. Isolation and characterization of human umbilical cord mesenchymal stem cells with hematopoiesissupportive function and other potentials. Haematologica 2006;91:1017-26. PubMed

132. Hsieh J-Y, Fu Y-S, Chang S-J, Tsuang Y-H, Wang H-W. Functional module analysis reveals differential osteogenic and stemness potentials in human mesenchymal stem cells from bone marrow and Wharton's jelly of umbilical cord. Stem Cells Dev 2010;19:1895910. DOI PubMed

133. Cho PS, Messina DJ, Hirsh EL, et al. Immunogenicity of umbilical cord tissue derived cells. Blood 2008;111:430-8. DOI PubMed

134. Deuse T, Stubbendorff M, Tang-Quan K, et al. Immunogenicity and immunomodulatory properties of umbilical cord lining mesenchymal stem cells. Cell Transplant 2011;20:655-67. DOI PubMed

135. Eggenhofer E, Benseler V, Kroemer A, et al. Mesenchymal stem cells are short-lived and do not migrate beyond the lungs after intravenous infusion. Front Immunol 2012;3:297. DOI PubMed PMC

136. Higashimoto M, Sakai Y, Takamura M, et al. Adipose tissue derived stromal stem cell therapy in murine ConA-derived hepatitis is dependent on myeloid-lineage and CD4+ T-cell suppression. Eur J Immunol 2013;43:2956-68. DOI PubMed

137. Cao H, Yang J, Yu J, et al. Therapeutic potential of transplanted placental mesenchymal stem cells in treating Chinese miniature pigs with acute liver failure. BMC Med 2012;10:56. DOI PubMed PMC

138. Li J, Zhang L, Xin J, et al. Immediate intraportal transplantation of human bone marrow mesenchymal stem cells prevents death from fulminant hepatic failure in pigs. Hepatology 2012;56:1044-52. DOI PubMed

139. Amin MA, Sabry D, Rashed LA, et al. Short-term evaluation of autologous transplantation of bone marrow-derived mesenchymal stem cells in patients with cirrhosis: Egyptian study. Clin Transplant 2013;27:607-12. DOI PubMed

140. Baertschiger RM, Serre-Beinier V, Morel P, et al. Fibrogenic potential of human multipotent mesenchymal stromal cells in injured liver. PloS One 2009;4:e6657. DOI PubMed PMC

141. di Bonzo LV, Ferrero I, Cravanzola C, et al. Human mesenchymal stem cells as a two-edged sword in hepatic regenerative medicine: engraftment and hepatocyte differentiation versus profibrogenic potential. Gut 2008;57:223-31. DOI PubMed

142. Krampera M, Cosmi L, Angeli R, et al. Role for interferon-gamma in the immunomodulatory activity of human bone marrow mesenchymal stem cells. Stem Cells 2006;24:386-98. DOI PubMed

143. Linero I, Chaparro O. Paracrine effect of mesenchymal stem cells derived from human adipose tissue in bone regeneration. PLoS One 2014;9:e107001. DOI PubMed PMC

144. Giuliani M, Bennaceur-Griscelli A, Nanbakhsh A, et al. TLR ligands stimulation protects MSC from NK killing. Stem Cells 2014;32:290-300. DOI PubMed

145. Kang SH, Kim MY, Eom YW, Baik SK. Mesenchymal stem cells for the treatment of liver disease: present and perspectives. Gut Liver 2020;14:306-15. DOI PubMed PMC

146. Liu Y, Xiong Y, Xing F. Precise regulation of miR-210 is critical for the cellular homeostasis maintenance and transplantation efficacy enhancement of mesenchymal stem cells in acute liver failure therapy. Cell Transplant 2017;9:805-20. DOI PubMed PMC

147. Bruno S, Collino F, Deregibus MC, Grange C, Tetta C, Camussi G. Microvesicles derived from human bone marrow mesenchymal stem cells inhibit tumor growth. Stem Cells Dev 2013;22:758-71. DOI PubMed

148. Studeny M, Marini FC, Champlin RE, Zompetta C, Fidler IJ, Andreeff M. Bone marrow-derived mesenchymal stem cells as vehicles for interferon-beta delivery into tumors. Cancer Res 2002;62:3603-8. PubMed

149. Xie C, Xie DY, Lin BL, et al. Interferon- $\beta$ gene-modified human bone marrow mesenchymal stem cells attenuate hepatocellular 
carcinoma through inhibiting AKT/FOXO3a pathway. Br J Cancer 2013;109:1198-205. DOI PubMed PMC

150. Su Y, Cheng R, Zhang J, et al. Interferon- $\alpha 2 \mathrm{~b}$ gene-modified human bone marrow mesenchymal stem cells inhibit hepatocellular carcinoma by reducing the Notch1 levels. Life Sci 2015;143:18-26. DOI PubMed

151. Sun XY, Nong J, Qin K, et al. MSC (TRAIL)-mediated HepG2 cell death in direct and indirect co-cultures. Anticancer Res 2011;31:3705-12. PubMed

152. Zhang B, Shan H, Li D, Li ZR, Zhu KS, Jiang ZB. The inhibitory effect of MSCs expressing TRAIL as a cellular delivery vehicle in combination with cisplatin on hepatocellular carcinoma. Cancer Biol Ther 2012;13:1175-84. DOI PubMed PMC

153. Chen X, Wang R, Zhao X, et al. Prophylaxis against carcinogenesis in three kinds of unestablished tumor models via IL12-geneengineered MSCs. Carcinogenesis 2006;27:2434-41. DOI PubMed

154. Lai RC, Yeo RWY, Tan KH, Lim SK. Exosomes for drug delivery - a novel application for the mesenchymal stem cell. Biotechnol Adv 2013;31:543-51. DOI PubMed

155. Kang K, Ma R, Cai W, et al. Exosomes secreted from CXCR4 overexpressing mesenchymal stem cells promote cardioprotection via Akt signaling pathway following myocardial infarction. Stem Cells Int 2015;2015:659890. DOI PubMed PMC

156. Mirotsou M, Zhang Z, Deb A, et al. Secreted frizzled related protein 2 (Sfrp2) is the key Akt-mesenchymal stem cell-released paracrine factor mediating myocardial survival and repair. Proc Natl Acad Sci U S A 2007;104:1643-8. DOI PubMed PMC

157. Wang X, Zhao T, Huang W, et al. Hsp20-engineered mesenchymal stem cells are resistant to oxidative stress via enhanced activation of Akt and increased secretion of growth factors. Stem Cells 2009;27:3021-31. DOI PubMed PMC

158. Herberg S, Shi X, Johnson MH, Hamrick MW, Isales CM, Hill WD. Stromal cell-derived factor-1 $\beta$ mediates cell survival through enhancing autophagy in bone marrow-derived mesenchymal stem cells. PloS One 2013;8:e58207. DOI PubMed PMC

159. Semenza GL. Hypoxia-inducible factor 1: control of oxygen homeostasis in health and disease. Pediatr Res 2001;49:614-7. DOI PubMed

160. Song H, Kwon K, Lim S, et al. Transfection of mesenchymal stem cells with the FGF-2 gene improves their survival under hypoxic conditions. Mol Cells 2005;19:402-7. PubMed

161. Liu N, Patzak A, Zhang J. CXCR4-overexpressing bone marrow-derived mesenchymal stem cells improve repair of acute kidney injury. Am J Physiol Renal Physiol 2013;305:F1064-73. DOI PubMed

162. Nakamura Y, Ishikawa H, Kawai K, Tabata Y, Suzuki S. Enhanced wound healing by topical administration of mesenchymal stem cells transfected with stromal cell-derived factor-1. Biomaterials 2013;34:9393-400. DOI PubMed

163. Jang YO, Cho M-Y, Yun C-O, et al. Effect of function-enhanced mesenchymal stem cells infected with decorin-expressing adenovirus on hepatic fibrosis. Stem Cells Transl Med 2016;5:1247-56. DOI PubMed PMC

164. Sun C, Li DG, Chen YW, et al. Transplantation of urokinase-type plasminogen activator gene-modified bone marrow-derived liver stem cells reduces liver fibrosis in rats. J Gene Med 2008;10:855-66. DOI PubMed

165. Lan L, Chen Y, Sun C, Sun Q, Hu J, Li D. Transplantation of bone marrow-derived hepatocyte stem cells transduced with adenovirus-mediated IL-10 gene reverses liver fibrosis in rats. Transpl Int 2008;21:581-92. DOI PubMed

166. Ji R, Zhang N, You N, et al. The differentiation of MSCs into functional hepatocyte-like cells in a liver biomatrix scaffold and their transplantation into liver-fibrotic mice. Biomaterials 2012;33:8995-9008. DOI PubMed

167. Mazzocchi A, Devarasetty M, Huntwork R, Soker S, Skardal A. Optimization of collagen type I-hyaluronan hybrid bioink for 3D bioprinted liver microenvironments. Biofabrication 2018;11:015003. DOI PubMed PMC

168. Skardal A, Smith L, Bharadwaj S, Atala A, Soker S, Zhang Y. Tissue specific synthetic ECM hydrogels for 3-D in vitro maintenance of hepatocyte function. Biomaterials 2012;33:4565-75. DOI PubMed PMC

169. Rashidi H, Alhaque S, Szkolnicka D, Flint O, Hay DC. Fluid shear stress modulation of hepatocyte-like cell function. Arch Toxicol 2016;90:1757-61. DOI PubMed PMC

170. Gieseck RL 3rd, Hannan NRF, Bort R, et al. Maturation of induced pluripotent stem cell derived hepatocytes by 3D-culture. PLoS One 2014;9:e86372. DOI PubMed PMC

171. Wang Y, Wang H, Deng P, et al. In situ differentiation and generation of functional liver organoids from human iPSCs in a 3D perfusable chip system. Lab Chip 2018;18:3606-16. DOI PubMed

172. $\mathrm{Hu} \mathrm{H}$, Gehart H, Artegiani B, et al. Long-term expansion of functional mouse and human hepatocytes as 3D organoids. Cell 2018;175:1591-1606.e19. DOI PubMed

173. Arufe MC, De la Fuente A, Fuentes-Boquete I, De Toro FJ, Blanco FJ. Differentiation of synovial CD-105(+) human mesenchymal stem cells into chondrocyte-like cells through spheroid formation. J Cell Biochem 2009;108:145-55. DOI PubMed

174. Zhang X, Hu M-G, Pan K, Li C-H, Liu R. 3D spheroid culture enhances the expression of antifibrotic factors in human adiposederived MSCs and improves their therapeutic effects on hepatic fibrosis. Stem Cells Int 2016;2016:4626073. DOI PubMed PMC

175. Uygun BE, Soto-Gutierrez A, Yagi H, et al. Organ reengineering through development of a transplantable recellularized liver graft using decellularized liver matrix. Nat Med 2010;16:814-20. DOI PubMed PMC

176. Wu F, Wu D, Ren Y, et al. Generation of hepatobiliary organoids from human induced pluripotent stem cells. $J$ Hepatol 2019;70:1145-58. DOI PubMed

177. Katsuda T, Ochiya T, Sakai Y. Generation of hepatic organoids with biliary structures. In: Tanimizu N, editor. Hepatic Stem Cells. New York: Springer; 2019. pp. 175-85. DOI

178. Takebe T, Zhang R-R, Koike H, et al. Generation of a vascularized and functional human liver from an iPSC-derived organ bud transplant. Nat Protoc 2014;9:396-409. DOI PubMed

179. Nie YZ, Zheng YW, Ogawa M, Miyagi E, Taniguchi H. Human liver organoids generated with single donor-derived multiple cells rescue mice from acute liver failure. Stem Cell Res Ther 2018;9:5. DOI PubMed PMC 
180. Studeny M, Marini FC, Dembinski JL, et al. Mesenchymal stem cells: potential precursors for tumor stroma and targeted-delivery vehicles for anticancer agents. J Natl Cancer Inst 2004;96:1593-1603. DOI PubMed

181. Rhee KJ, Lee JI, Eom YW. Mesenchymal stem cell-mediated effects of tumor support or suppression. Int J Mol Sci 2015;16:3001533. DOI PubMed PMC

182. Hanahan D, Weinberg RA. Hallmarks of cancer: the next generation. Cell 2011;144:646-74. DOI PubMed

183. Orimo A, Gupta PB, Sgroi DC, et al. Stromal fibroblasts present in invasive human breast carcinomas promote tumor growth and angiogenesis through elevated SDF-1/CXCL12 secretion. Cell 2005;121:335-48. DOI PubMed

184. Hung SC, Pochampally RR, Chen SC, Hsu SC, Prockop DJ. Angiogenic effects of human multipotent stromal cell conditioned medium activate the PI3K-Akt pathway in hypoxic endothelial cells to inhibit apoptosis, increase survival, and stimulate angiogenesis. Stem Cells 2007;25:2363-70. DOI PubMed

185. Hung SC, Pochampally RR, Hsu SC, et al. Short-term exposure of multipotent stromal cells to low oxygen increases their expression of CX3CR1 and CXCR4 and their engraftment in vivo. PloS One 2007;2:e416. DOI PubMed PMC

186. Crisostomo PR, Wang Y, Markel TA, Wang M, Lahm T, Meldrum DR. Human mesenchymal stem cells stimulated by TNF-alpha, LPS, or hypoxia produce growth factors by an NF kappa B- but not JNK-dependent mechanism. Am J Physiol Cell Physiol 2008;294:C675-82. DOI PubMed

187. Dias S, Shmelkov SV, Lam G, Rafii S. VEGF(165) promotes survival of leukemic cells by Hsp90-mediated induction of Bcl-2 expression and apoptosis inhibition. Blood 2002;99:2532-40. DOI PubMed 